\title{
THE EFFECTIVENESS OF DISCOVERY LEARNING IN IMPROVING ENGLISH WRITING SKILL OF EXTROVERTED AND INTROVERTED STUDENTS
}

\author{
Daniar Sofeny \\ English Education Program, Darul 'Ulum Islamic University, Lamongan \\ Email: daniarsofeny@ymail.com
}

\begin{abstract}
This study aimed to describe the effectiveness of discovery learning in improving English writing skill of extroverted and introverted students which is compared with direct instruction as the traditional learning method. In this research, the researcher employed a quantitative research by using experimental factorial design. The population in this research was the eleventh graders of state senior high school Sale in academic year 2013/2014 and the samples were 20 students from both classes and categories. The try out was conducted to measure validity and reliability. And the two ways ANOVA was conducted to test the hypotheses, two -way analysis of variance with F-test at the 5\% (0.05) level of significance. The result of this study revealed that the use of discovery learning was effective to the extroverted students than the introverted students. In line with it, the finding indicates that the use of direct instruction was also effective to introverted students than the extroverted students. In other words, the result of the used of discovery learning had a bigger influence to the extroverted students rather than introverted students.
\end{abstract}

Keywords: Discovery Learning; Extroverted; Introverted; Writing Skill.

\begin{abstract}
ABSTRAK
Penelitian ini bertujuan untuk mendeskripsikan efektivitas penemuan pembelajaran untuk meningkatkan kemampuan menulis dalam bahasa Inggris pada siswa ekstrovert dan introvert yang dibandingkan dengan instruksi langsung sebagai metode pembelajaran tradisional. Dalam penelitian ini, peneliti menggunakan metode penelitian kuantitatif dengan memanfaatkan rancangan penelitian rancangan faktorial. Populasi data dalam penelitian adalah 11 orang siswa kelas sebelas di SMA Negeri di tahun akademik 2013/2014 dan sample dalam penelitian ini adalah 20 orang siswa dari kedua kelas dan kategori. Percobaan awal dilakukan dengan tujuan untuk mengukur validitas dan reliabilitas. Pendekatan INOVA dua cara dilakukan untuk mengetes hipotesis dan mengetesnya dengan analisis dua cara F-test pada tingkatan signifikansi 5\% (0.05). Hasil dari penelitian ini menunjukkan bahwa pemanfaatan pembelajaran discovery lebih efektif untuk siswa yang ekstrovert daripada untuk siswa yang introvert. Selain itu, temuan ini mengindikasikan bahwa pemanfaatan instruksi langsung juga lebih efektif untuk siswa intrivert dari pada siswa ekstrovert. Dengan kata lain, pemanfaatan pembelajaran discovery memiliki pengaruh yang lebih besar terhadap siswa ekstrovert dari pada siswa introvert.
\end{abstract}


Kata kunci: Discovery learning, siswa ekstrovert, siswa introvert, kemampuan menulis

\section{INTRODUCTION}

The new curriculum (2013 curriculum) for education system in Indonesia has been gradually implemented since the beginning of 2013/ 2014 academic year, July 2013. The Education and Culture Minister, Muhammad Nuh, said that not all schools would implement the 2013 curriculum. It means that this new curriculum will be carried out in stages, and in 2015 all the schools in Indonesia will have been implementing it, including schools in remote areas.

There are three model of learning which implemented in the 2013 curriculum, such as project based curriculum, problem based curriculum, and discovery learning. Here, the researcher chose discovery learning to be the main discussion which would be correlated to the development of English writing skill and two types of personality.

This study is significant due to some reasons. Firstly, the researcher is interested to understand more widely concerning more practical teaching writing skill. So, the researcher can get valuable information about how students can develop their competence in writing skill especially in writing private letter.

Secondly, the researcher is interested in extroversion-introversion personality because she believes that by understanding the students' personality types, teachers can adjust their teaching to foster individual success.

When the teachers start to understand the behavior of students with different personalities, they can adjust the structure and flow of their classroom to allow for success for more students. This shift in teacher attitude toward students of color is crucial, given the prevalence among educators of the "deficit model" for children of color, where their cultural differences are viewed as problems to be overcome rather than diversity that can be drawn upon. (Lipman, 1998).

Thirdly, as has been mentioned in the background of the study, this current study was aimed to investigated the most effective learning method that is discovery learning to the extroverted and introverted students in teaching and learning of writing skill to the students from experimental and control groups from the two categories of Psychological types, they are extroverted and introverted learners. The researcher chose merely both of categories of psychological types because they related to the learning of writing skill.

There are eight statement of the problems in this study. First, what types of personalities do of the eleventh graders in the state senior high school 1 Sale belong to?. Second, how effective is the use of direct instruction for teaching English writing skill to the extroverted students?. Third, how effective is the use of direct instruction for teaching English writing skill to the introverted students?. Fourth, how effective is the use of discovery learning for teaching English writing skill to the extroverted students? Fifth, how effective is the use of discovery learning for English writing skill to the introverted students?. Sixth, how do the students' perform in English writing after being taught using direct instruction?. Seven, how do the students' perform in English writing after being taught using discovery learning?. And the last, is there any interaction among learning method, psychological types, and the students' writing skill?

The study will examine the types of personality do of the eleventh graders in the state senior high school 1 Sale belong to. The second objective is examining the use of direct 
instruction for teaching English writing skill to the extroverted and introverted students. The study also will examine about the use of discovery learning for teaching English writing skill to the extroverted and introverted students. Furthermore, the students' perform in English writing after being taught using direct instruction and discovery learning will be examined too. The last case which will be examined is about the interaction among learning method, psychological types, and the students' writing skill.

\section{REVIEW OF RELATED LITERATURE}

There are some reviews of related literature as follows:

\section{Discovery Learning Model}

Discovery learning is when a student obtains knowledge by him/herself. It involvesconstructing and testing hypotheses rather than passively reading or listening to teacher presentations (Schunk, 2008). Discovery learning can also be referred to as problembased, inquiry, experiential, or constructivist learning. It involves inductive reasoning because students move from a specific topic to formulating rules and principles (Kirschner, Sweller, \& Clark, 2006). Over the past decade, research on this form of learning has moved from concept discovery learning towards authentic discovery learning, which is characterized by designing scientific experiments (Reid, Zhang, \& Chen, 2003).

Talking about the strengths and weaknesses of discovery learning are important. Firstly about the strength of discovery learning including, builds on learner's prior knowledge and understanding, develops a sense of independence of autonomy, enables the development of lifelong learning skills, supports active engagement of the learner, develops meta cognitive skills (including some higher level cognitive strategies), highly motivates as it allows individuals the opportunity to experiment and discover something for themselves; fosters curiosity a reason to record their procedure and discoveries - such as not repeating mistakes, a way to analyze what happened, and a way to record a victorious discovery, personalizes the learning experience, develops problem solving and creative skills, and the last is promote lifelong learning.

Otherwise, the weaknesses also followed, such as: Cognitive overload, potential to confuse the learner if no initial framework is available, measurable performance (compared to hard-core teaching designs) is worse for most learning situations, creations of misconceptions ("knowing less after instruction"), weak students have a tendency to "fly under the radar" and teachers fail to detect situations needing strong remediation or scaffolding, some studies admit that strong students can benefit from weak treatments and others conclude that there is no difference, but more importantly they also conclude that weak students benefit strongly from strong treatments, science is very hard and indeed puts a very heavy load on short-term memory. In addition, in order to solve even moderately complex problems a person must engage many schemas. If nothing is available in long term memory, the learner is stuck, Weak students tend to "sweep under the carpet" issues that were not understood, using this method, teachers find it difficult to identify situations that require strong recovery or scaffolding. Particularly in the group discovery process is a serious weakness, discovery learning, like most constructivist instructional design models is not easy to implement, since learners need to possess a number of cognitive skills and be intrinsically motivated to learn, guided discovery may control learning behavior and could therefore be abused, and is designed for individual rather than group use.

\section{Writing Competence}

According to Concise Oxford English Dictionary, 'competence' sharessimilar meaning to

'skill'. Both express the quality, ability, or knowledge to dosomething successfully. On basic 
level, writing can refer to forming or producinggraphic symbols on the surface of some flat thing. On the upper level, writing isnot merely arranging those graphic symbols without any rule. It should be basedon certain convention to form words and then sentences, to form them intoparticular order and linked together (Byrne, 1991: 1).

\section{Personality}

Personality is what makes our actions, thoughts and feelings consistent (orrelatively consistent), and it is also what makes us different fromone another. (Child, 1969).

\section{Extrovert and Introvert Personality}

According to Curl G. Jung's theory (1971: 6) of Psychological Types we are all different in fundamental ways. One's ability to process different information is limited by their particular type. Extroverts are directed towards the objective world whereas Introverts are directed towards the subjective world.

Extrovert are interested in what is happening around them, are open and often talkative, compare their own opinions with the opinions of others, like action and initiative easily make new friends or adapt to a new group, say what they think, interested in new people, easily break unwanted relations.

Otherwise, introvert are interested in their own thoughts and feelings, need to have own territory, often appear reserved, quiet and thoughtful, usually do not have many friends, have difficulties in making new contacts, like concentration and quiet, do not like unexpected visits and therefore do not make them, work well alone.

\section{RESEARCH METHOD}

This research method consists of some parts, they are:

\section{Design of the Study}

In this research, the grand design was experimental or an intervention study. Kind of experimental research that was used in this research is factorial design which wishes to understand the effect of two or more independent variables upon a single dependent variable. The independent variable is the use of Discovery Learning technique in teaching writing. The dependent variable is the writing skill of students in the eleventh graders of the first state senior high school Sale. For the moderating variable is the extrovert and introvert students. As it was factorial design, the researcher uses the pre-test-post-test for the control and the experimental group design.

\section{Population and Sample}

In this study, the population was the eleventh graders of the first state senior high school Sale. They come from two classes which are nearly homogenous in their English ability. They are purposively chosen as the researcher believes that they were representative.

In this study, there were approximately 20 students of the first state senior high school Sale from the eleventh graders took part. Thus, the researcher is relatively confidents in choosing them as the participants of the study. The selected participants were divided into two groups; 10 students were grouped into experimental group and other 10 students were grouped into control group. The experimental group got some treatment using discovery learning and the control group got treatment using direct instruction.

\section{Research Procedure}

This research process had been done through the following steps, firstly the researcher had 
provided pre test (first draft) for both the experimental and control groups, secondly, treatments had been given by giving direct and indirect corrective feedback on students' writing skill, the last, post test (second draft) for both experimental and control group. It had been done to get the data about the result of treatments in the experimental and control group.

\section{RESEARCH FINDINGS}

This research was aimed at knowing the differences on the result of students' writing skill using discovery learning at the first state senior high school Sale as the research site. The treatment was given to experimental class which then compared to another class - control class. The data were gained through some instruments of the tests such as try out, pretest, and post test.

Based on observation and then calculated using SPSS ${ }^{16}$ the $t$ value of pre test and post test is 7.506 with the degree of significance 0.05 . Based on the table the value of $t$ for $\mathrm{df} 4$ is 2.776 or based on the table above we can see $t_{\text {count }}$ more than $t_{\text {table }}$ at significance $\alpha 0.05$ or $7.506 \geq$ 2.776 it means Ho is rejected and Ha is accepted.

From that explanation, it can be recognized that the value of $T$ test for the mark of pre test and post test coming from the result of the students' learning process, comprising for introverted students indicated that $\mathrm{Ha}$ is accepted. Those calculations can be the basis for the assumption that the result of students' learning process, comprising of introverted students in experimental class, provided significant differences if they get the treatment of discovery learning in writing class.

Firstly, the finding indicated that the use of discovery learning was effective to the extroverted students. Secondly, the finding indicates that the use of discovery learning was less effective to the introverted students. Thirdly, the finding indicates that the use of direct instruction was effective to the extroverted students. Fourthly, the finding indicates that the use of direct instruction was less effective to the introverted students. Fifthly, the finding indicates that the use of discovery learning was effective in experimental class. Sixthly, the finding indicates that the use of direct instruction was less effective in control class. And the last, the probability which was based on the personality was $0.806<2.101$, there was difference between personality types and the usage of method. There was an interaction among learning methods, discovery learning, students' personalities, and English writing skill. The result of the used of discovery learning had a bigger influence to the extroverted students rather than introverted students.

\section{CONCLUSION AND SUGESSTION}

Conclusion and suggestion based on finding and discussion of the data analysis as follows:

\section{Conclusion}

From the result of the analysis, it can be concluded that: firstly, the finding indicates that teaching writing skill through the use of discovery learning to extroverted students in effective. It was conducted in experimental group.

Secondly, teaching writing skill through the use of discovery learning to introverted students is less effective in experimental class. It can be seen from the result post test.

Thirdly, teaching writing skill to the introverted students by using the method of discovery learning is less effective. Fourthly, teaching writing skill to the introverted students by using the method of direct instruction. The statistical findings proved that teaching writing skill to the introverted students employing direct instruction is more effective than that of extroverted 
students. Fifthly, the result of students' writing skill in experimental group, the data demonstrates that experimental group used the discovery learning considered as the method of writing skill, the data betterment than the use of the method direct instruction. It is provided on personality types - extroverted students.

Sixthly, the result of the students' writing skill in control group, the data demonstrates that control group used direct instruction considered as the method of teaching writing skill of English. The data which have been found indicates that the use of direct instruction more effective to the introverted students. And the last, there are interaction among discovery learning method, psychological types and students' writing skill.

\section{Suggestion}

The data demonstrated that employing the method of discovery learning is much more effective than that of direct instruction in teaching students' writing skill. In addition, the use of both discovery learning and direct instruction are effective in teaching writing skill to intuitive students as well. Based on that reason, the researcher puts her proposition to other researchers as follows.

Firstly, the respondents for another experimental research can be derived from those who are coming from other reasonable level of competence in their English. Secondly, the same techniques can be used in other research sites such as school and other formal or informal English institution. Thirdly, other forms of the method of discovery learning and direct instruction can be used to teach writing skill in other study. Fourthly, the method of discovery learning and direct instruction can be applied to teach other language competence such as speaking, reading, or listening. The last, all categories of personality types can be employed to investigate the effectiveness the discovery learning and direct instruction in teaching students writing skill.

\section{REFERENCES}

Briggs Myers, I. 1980, 1995. Gifts Differing: Understanding Personality Type.

Brown, H. 2000. Principles of Language Learning and Teaching. 4th ed. White Plains, NY: Addison Wesley Longman

Castronova J.A.Discovery learning for the 21st century: what is it and how it compares to traditional learning in effectiveness in the 21st century? http://teach.valdosta.edu/are/ Litreviews/vollnol/castronova_litr.pdf

Gilakjani, A. P. 2012. Visual, Auditory, Kinaesthetic Learning Style and Their Impacts on English Language Teaching, Journal of Studies in Education. English Language Department, Islamic Azad University, Lahijan, Iran, Vol. 2 (1), pp. 104-113.

Jung, C. G. 1971. Psychological types (Collected works of C. G. Jung, volume 6, Chapter X)

Wakamoto, N. 2001. Language Learning Strategies Used by Japanese College Learners of English: A synthesis of four Empirical Studies. Language Education and Technology 38, 21-43.

Waterman, Sarabeth. 2013. The Effect of Discovery Learning: The effect of brainscape's confidence-based repition on two adults 'performance on knowledge-based quizzes. New York: the state university of New York. 